\title{
Reservoir characterization and prospect identification in Onka field, offshore, Niger Delta
}

\author{
Olatunbosun O. Kafisanwo $^{1 *}$, Ayodele O. Falade ${ }^{1}$, Olanrewaju V. Bakare ${ }^{2}$, Ayokunle A. Oresanya ${ }^{3}$ \\ ${ }^{1}$ Department of Applied Geophysics, Federal University of Technology, Akure 340252, Nigeria \\ ${ }^{2}$ Department of Geosciences, University of Lagos, Lagos 100213, Nigeria \\ ${ }^{3}$ All Grace Energy Limited, Abuja 900211, Nigeria
}

Corresponding Author Email: olatunbosun.kafi@gmail.com

https://doi.org/10.18280/eesrj.050401

Received: 10 October 2018

Accepted: 30 November 2018

\section{Keywords:}

seismic, reservoir characterization, Niger-Delta, prospect evaluation, petrophysics, Onka field, offshore, geology

\begin{abstract}
The study is focused on the use of 3D seismic, well logs and checkchots data to delineate, evaluate and characterize reservoirs relating to their hydrocarbon potentials. Four localized wells were available for this study. The study location is Onka field, offshore, Niger Delta. Well correlation and detailed petrophysical analysis was carried out along all the wells. Three reservoirs were discerned within the agbada formation. Among these delineated reservoirs, reservoir 2 occurs to be the most prolific with average gross thickness of about $49 \mathrm{ft}$, net pay thickness of about $43 \mathrm{ft}$, average net to gross thickness of approximately $71 \%$, a good porosity of $20 \%$ and hydrocarbon saturation of $81 \%$ which is more blatant in well DESLA 1ST2. Seismic interpretation shows the presence of 26 faults. The faulting system corresponds with the geology of the Niger Delta. From the generated structural surface map of Reservoir 2, Fault F7 at the flank of the crest forms an antithetic fault type with both F7A and F7B. This also aligns with the mundane trapping system of the study area. It is recommended that more wells should be drilled at strategic locations to provide more data that will contribute to quality reservoir models.
\end{abstract}

\section{INTRODUCTION}

Data is the next oil and this also applies to oil and gas exploration as it is getting more expensive to acquire. Therefore, making judicious use of the limited data available in order to make viable decisions, has become necessary as the cost of acquiring these data is increasing with time.

Many researchs have being carried out in order to have a better understanding of reservoir structures while minimizing the cost of exploration and production. Peng et al. [1] proposed a new method to tackle the quality of DST test during early evaluation stage in offshore gas reservoirs. Li et al. [2] also tried to explore reservoirs with low resistivities due to high mineralized formation water, high clay content among many other factors that might affect a reservoir formation.

The information gotten from previous nearby field are important and should contribute to whole interpretation process. However, one should also not be blind to the fact that the subsurface whose properties and structure we are trying to determine and visualize might deviate from the norm as a result of several abnormal conditions, especially in complex geological settings.

According to Adeoti and Abe et al. [3-4] among other related researches, the generation of quality reservoir models has proven for decades to be a reliable approach for the detail study of reservoir structures and its properties. Abe et al. [4] made use of seismic and distributed well log data within reservoirs using geostatic approach across the reservoirs to study and characterize them according to their qualities. However, one of the factors that determine a quality reservoir is attributed to the amount of data inputted in the process of its generation.

This project "Reservoir Characterization and Prospect Identification in Onka Field, Offshore, Niger Delta" made use of seismic and available localized well data to get a better knowledge of the present reservoirs. In this case, we have a novel field with limited and localized well data. The results acquired from the interpretation will serve as the basis for the recommendation of developmental well locations. It will help to determine new verdant areas to acquire extended data in order to fully explore the potentials of the field.

\section{MATERIALS AND METHODOLOGY}

The materials available for this research are 3D seismic data and well logs suites. Litho-stratigraphic correlation was done using the available lithology log (gamma ray log) to distinguish between the two basic lithology types (i.e; sand and shale) dominant in the field according to the geology of the Niger Delta [5]. A cut off was established from the statistics of the Gamma Ray log in order to differentiate between sands with low Gamma Ray values and shales which possess high radioactive content with corresponding high Gamma Ray values. Resistivity log was used to identify the present fluid type (i.e.; formation water and/or hydrocarbon) and the hydrocarbon type was then distinguished with neutron-density crossover.

These factors were used to identify prospective reservoirs units and petrophysical analysis were carried out on them. Synthetic seismogram was generated using both sonic and density logs. Seismic to well tie was then executed to establish a relationship between seismic and well data. This 
process also helps to know the events to be picked as horizons on seismic lines. Seismic interpretation, which involves the picking of faults and identified events as horizon across seismic line, was done. Taking cognizance of faults orientation, the picked horizons were interpolated to generate surface time maps which were converted to their corresponding structural depth maps with the aid of a velocity model.

\section{LOCATION AND GEOLOGY OF STUDY AREA}

\subsection{Location of study area}

The study area is geographically located offshore Niger Delta within Latitude $1^{\circ} 23^{\prime} 26.357^{\prime}$ ' and Longitude $4^{\circ} 25^{\prime}$
41.234". The seismic survey covers 389 In lines and 1263 Crosslines. Four wells were drilled namely DESLA1, DESLA 1ST1, DESLA 1ST2 AND DESLA 2. DESLA 1, DESLA 1ST1 and DESLA 1ST2 are drilled from same location but deviated along different path. However, DESLA 2 was drilled from different point of about $1 \mathrm{~km}$ away from the other wells. According to the observation on well $\log$, DESLA 2 is a dry hole with no vestiges of hydrocarbon but other wells shows evidence of hydrocarbon.

\subsection{Geology of study area}

Niger Delta basin is an extensional rift basin in the Niger Delta and the Gulf of Guinea on the passive continental margin near the Western coast of Nigeria [6].

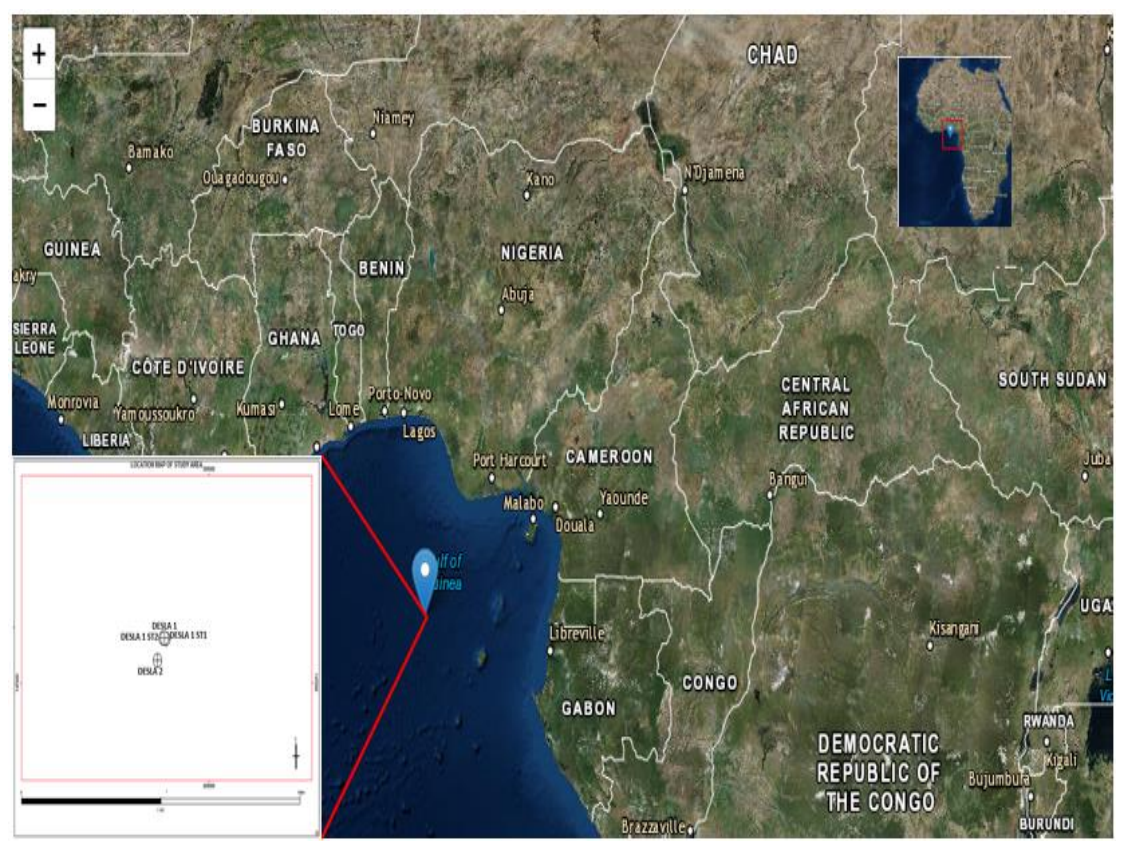

Figure 1. Location of study area

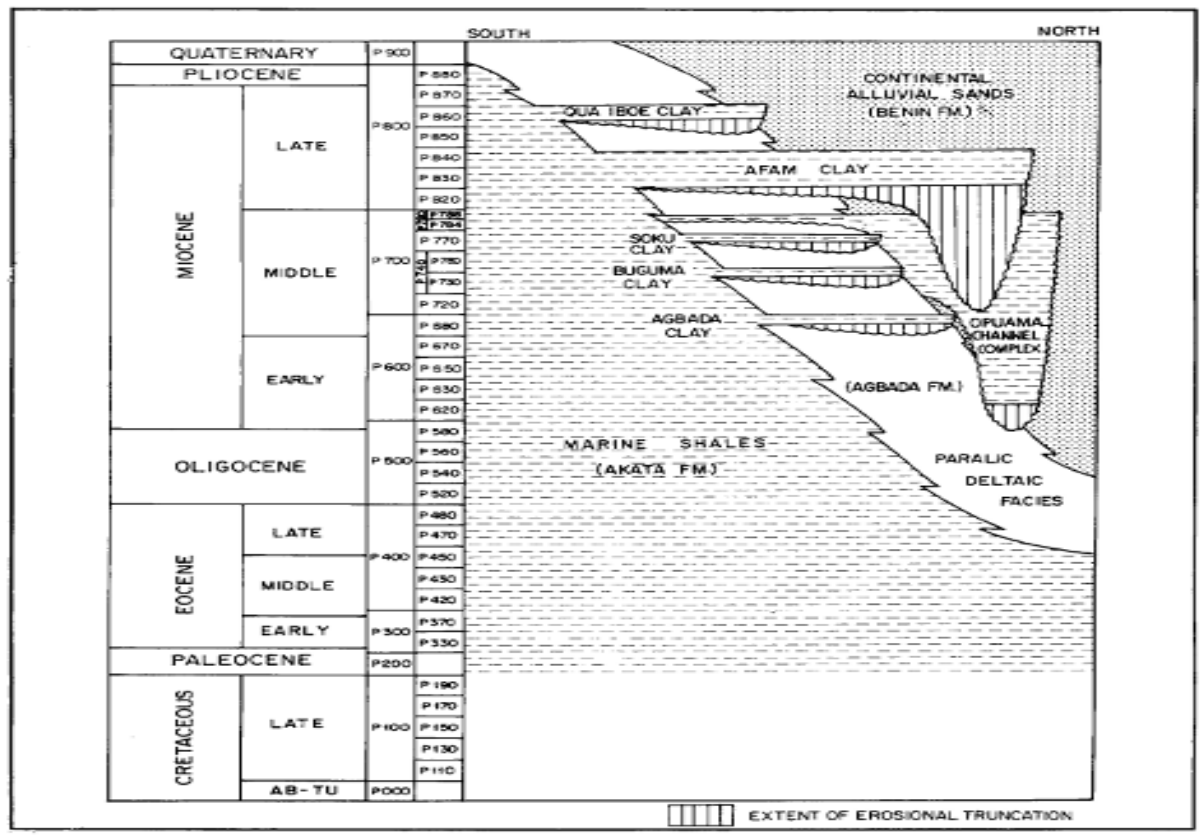

Figure 2. A stratigraphy column with the three formation present in Niger Delta [6] modified by Doust and Omatsola [13] 
The clastic wedge of the Niger Delta occurs along a failed arm of a triple junction systems which was formerly emanated during the breakup that occurred between South American and African plates. This process happened in the late Jurassic [7].

The age of this basin as defined by Klett et al. [8] extends from Eocene to the present, the delta has prograded southward, forming depobelts that accounts for one of the largest regressive deltas in the world with thickness of over $10 \mathrm{~km}$ [9], an area of some $300,000 \mathrm{~km}^{2}$ [5], and a sediment volume of $500,000 \mathrm{~km}^{3}$ [10]. The petroleum system of Niger Delta province is referred to as the Tertiary Niger Delta (Akata -Agbada) petroleum system [11]. The Tertiary section of the Niger Delta is divided into three lithostratigraphic formations units [12].

First, the deep-seated Akata formation with thickness of about $6,400 \mathrm{~m}$ at the centre of the clastic wedge. This overpressured, ductile dark marine shale and silts (with streaks of sand of turbidite flow origin) is the potential source rock unit. The age of the Akata is from Paleocene to Recent and it grades vertically into the overlying Agbada formation [13]. The second formation is Agbada formation, it is known as the major hydrocarbon bearing unit consisting of paralic siliclastics basically sandstone with intercalations of shale. It is further overlain by the Benin formation, which is characterized by poorly sorted, medium to fine grained radioactive sands and gravels with vestiges of shale. The structural features present in the Niger Delta which also serves as the trapping mechanisms are simple rollover structures with clay filled channel, growth faults, antithetic fault and collapsed crest.

\section{PRESENTATION AND DISCUSSION OF RESULTS}

\subsection{Well log interpretation}

The orientation of the well log correlation was from NorthWest to North-East. DESLA 1 is the first and only vertical well drilled in the field with total MD of $13,620 \mathrm{ft}$. It cuts across the three delineated reservoirs with presence of hydrocarbon more evident in reservoir 2. DESLA1ST1 and DESLA2ST2 have total MD of $8,862 \mathrm{ft}$ and $8,800 \mathrm{ft}$ respectively. They are both wells drilled at the same location as DESLA 1 but they deviated along different paths. DESLA 2 is also a deviated well located $1172 \mathrm{~m}$ away from the other wells with a total MD of $10,080 \mathrm{ft}$. This well also cut across the three reservoirs. However, it is a dry well (i.e. no observed presence of hydrocarbon). Figure 3 and Figure 4 shows the correlation panel with the delineated reservoir unit on all the available wells.

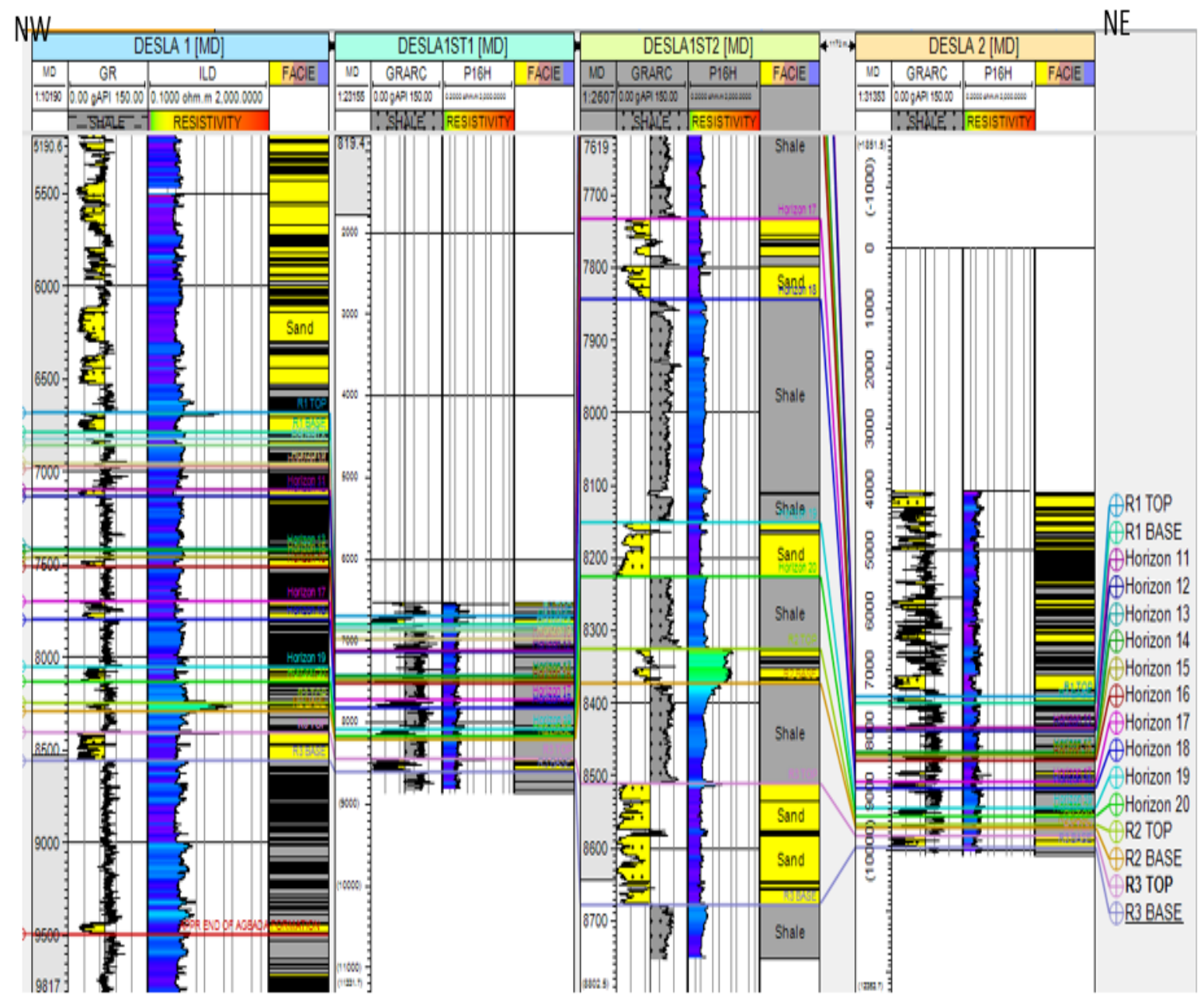

Figure 3. Well log correlation showing the some of sand units and reservoir present across the wells 


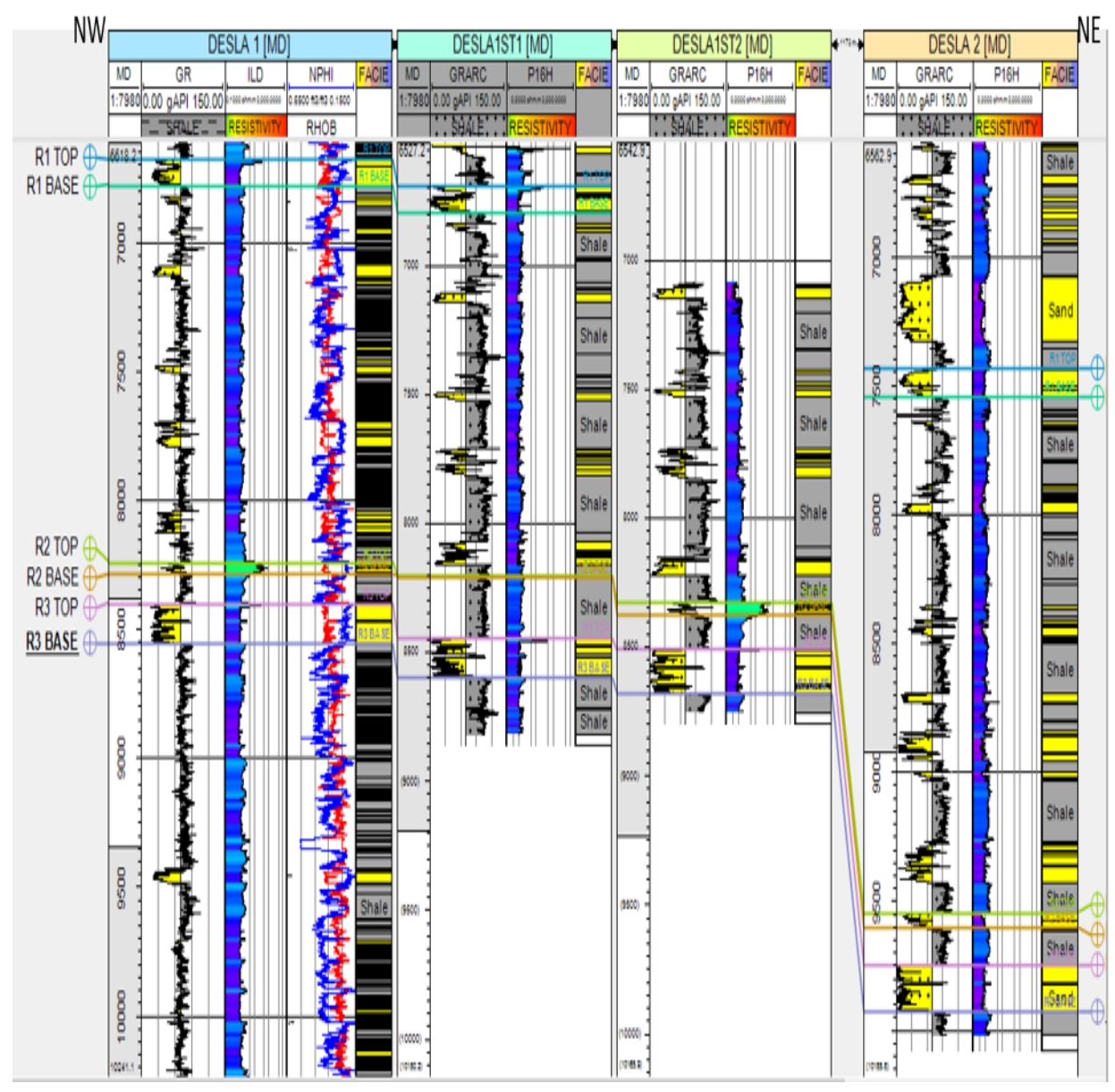

Figure 4. Well log interpretation showing the correlation of delineated reservoir across the wells

\subsection{Petrophysical evaluation and analysis}

\subsubsection{Petrophysical evaluation and analysis of reservoir 1}

The petrophysical evaluation table and charts of Reservoir 1 are displayed in Table 1 and Figure 5 respectively. This is the first encountered reservoir located within the Agbada formation with traces of hydrocarbon. The gross thickness of this reservoir increases eastward from DESLA 1 to DESLA 2 with an average gross thickness of $104 \mathrm{ft}$, an average net to gross thickness of about $84 \%$. It has an average porosity of $26 \%$ and an average hydrocarbon saturation of $20 \%$ as evident on both DESLA 1 and DESLA1ST1.

Table 1. Petrophysical table of reservoir 1

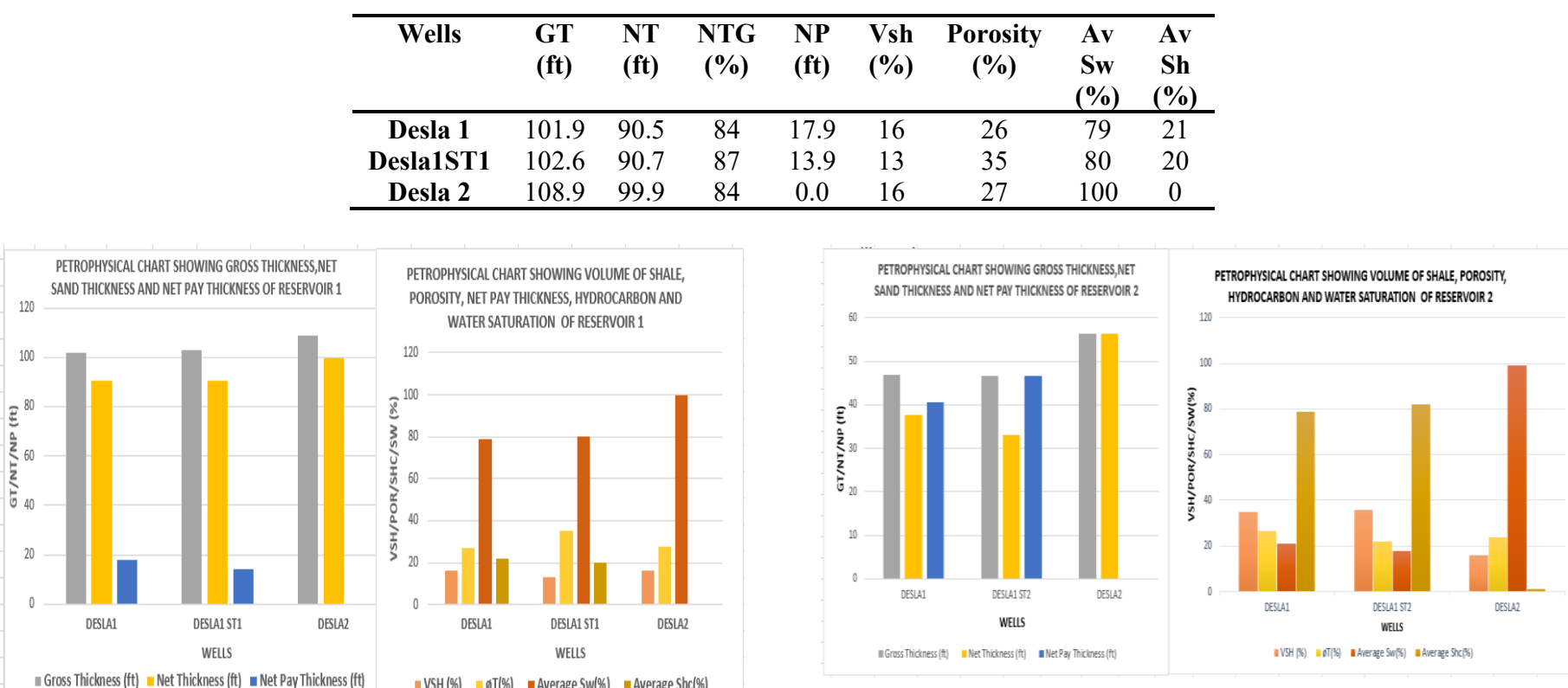

Figure 5. Petrophysical chart of Reservoir 1

Figure 6. Petrophysical chart of Reservoir 2 
Table 2. Petrophysical table of Reservoir 2

\begin{tabular}{ccccccccc}
\hline Wells & $\begin{array}{c}\text { GT } \\
(\mathbf{f t})\end{array}$ & $\begin{array}{c}\text { NT } \\
(\mathbf{f t})\end{array}$ & $\begin{array}{c}\text { NTG } \\
(\%)\end{array}$ & $\begin{array}{c}\text { NP } \\
(\mathbf{f t})\end{array}$ & $\begin{array}{c}\text { Vsh } \\
(\%)\end{array}$ & $\begin{array}{c}\text { Porosity } \\
(\%)\end{array}$ & $\begin{array}{c}\text { Av } \\
\text { Sw } \\
(\%)\end{array}$ & $\begin{array}{c}\text { Av } \\
\text { Sh } \\
(\%)\end{array}$ \\
\hline Desla 1 & 46.8 & 37.7 & 65 & 40.6 & 35 & 27 & 21 & 79 \\
Desla1ST1 & 46.7 & 33.0 & 64 & 46.7 & 36 & 22 & 18 & 82 \\
Desla 2 & 56.4 & 56.4 & 64 & 0.0 & 16 & 24 & 99 & 1 \\
\hline
\end{tabular}

\subsubsection{Petrophysical evaluation and analysis of reservoir 2}

Reservoir 2 is one with an average gross thickness of about 49ft with the highest of about 56ft found on well DESLA 2. It has a moderately clean unit with average net sand thickness of about $40 \mathrm{ft}$ and average volume of shale of about $25 \%$. From the petrophysical evaluation as seen in Figure 6 and Table 2.

This reservoir is the most prolific hydrocarbon bearing unit when compared to the other two detected reservoirs. It has an average net pay thickness of about 43ft, an average hydrocarbon saturation of about $82 \%$ and corresponding average porosity of $23 \%$.

\subsubsection{Petrophysical evaluation and analysis of reservoir 3}

Reservoir 3 is the deepest reservoir found in the field. It also saddles across the four wells with an average gross thickness of $155 \mathrm{ft}$ and average volume of shale of $10 \%$ which makes it a very clean reservoir unit with little or no shale intercalations. It has a net pay thickness of about $10 \mathrm{ft}$ and average hydrocarbon saturation at $13 \%$ across the wells. However, the reservoir shows a $100 \%$ water saturation on DESLA 2. The petrophysical evaluation and analysis of reservoir 3 is displayed in Table 3 and Figure 7.

Reservoir 2 is observed to be the most promising reservoir. It can be seen from the chart in Figure 7 that DESLA2 have the thickest delineated unit and also have the highest sand thickness. However, DESLA1ST2 is observed to have the highest net pay, a good net to gross, a reasonable effective porosity of about $20 \%$ with the highest hydrocarbon saturation of $82 \%$ which makes it the most promising well for hydrocarbon extraction of this reservoir.

Table 3. Petrophysical table of reservoir 3

\begin{tabular}{ccccccccc}
\hline Well & $\begin{array}{c}\text { GT } \\
\text { (ft) }\end{array}$ & $\begin{array}{c}\text { NT } \\
(\mathbf{f t})\end{array}$ & $\begin{array}{c}\text { NTG } \\
(\%)\end{array}$ & $\begin{array}{c}\text { NP } \\
(\mathbf{f t})\end{array}$ & $\begin{array}{c}\text { Vsh } \\
(\mathbf{\%})\end{array}$ & $\begin{array}{c}\text { Porosity } \\
(\%)\end{array}$ & $\begin{array}{c}\text { Av } \\
\text { Sw } \\
(\%)\end{array}$ & $\begin{array}{c}\text { Av } \\
\text { Sh } \\
(\%)\end{array}$ \\
\hline Desla 1 & 154.3 & 146 & 87 & 12.2 & 13 & 25 & 84 & 16 \\
Desla1ST1 & 149.4 & 136.7 & 88 & 10.5 & 12 & 36 & 84 & 16 \\
Desla 2 & 166.9 & 167.6 & 92 & 3.4 & 8 & 39 & 90 & 10 \\
\hline
\end{tabular}
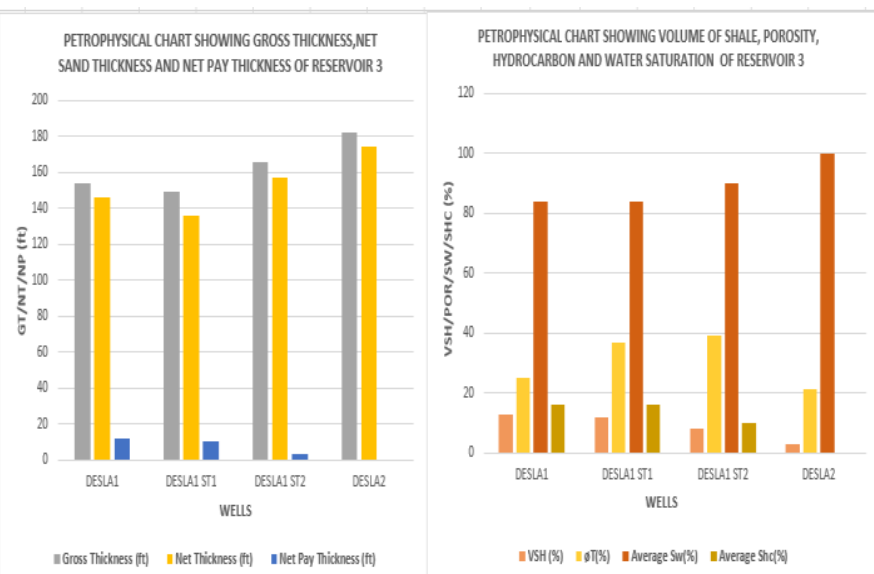

\subsection{Horizon and fault Interpretation}

Fault interpretation was done and faults were picked on inlines across the whole seismic volume. Figure 8 shows the faults and horizons picked on a seismic section (Inline 10590). A total of 26 faults including 11 major faults and 15 minor faults were discovered. Most of the faults were observed to dip south-eastward with the exception of F15, F7 and F7B that dips in the opposite direction.

Prior to picking of horizon, the well to seismic tie was done to help match the seismic traces to synthetic seismogram and also identify the event of horizons. The event of each horizon and their approximate time of seismic is shown in Table 4 below.

Figure 7. Petrophysical chart of Reservoir 3

Table 4. A table showing the event and corresponding seismic time of delineated reservoirs

\begin{tabular}{|c|c|c|c|c|}
\hline Reservoirs & $\begin{array}{c}\text { Top } \\
\text { event }\end{array}$ & $\begin{array}{c}\text { Top } \\
\text { seismic } \\
\text { time } \\
(\mathrm{ms}) \\
\end{array}$ & $\begin{array}{c}\text { Base } \\
\text { event }\end{array}$ & $\begin{array}{c}\text { Base } \\
\text { seismic time } \\
(\mathrm{ms})\end{array}$ \\
\hline $\begin{array}{c}\text { Reservoir } \\
1\end{array}$ & Trough & 1788.8 & Crossover & 1790.5 \\
\hline $\begin{array}{c}\text { Reservoir } \\
2\end{array}$ & Peak & 2100.6 & Trough & 2109.2 \\
\hline $\begin{array}{c}\text { Reservoir } \\
3\end{array}$ & Trough & 2130.2 & Peak & 2156.8 \\
\hline
\end{tabular}




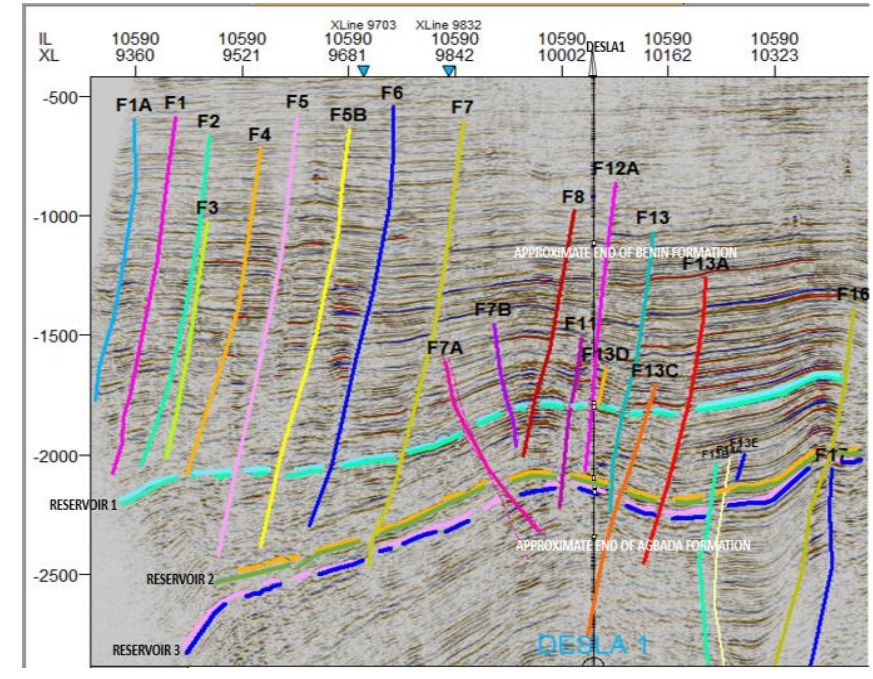

Figure 8. Seismic Interpretation showing some faults and horizons of reservoirs picked on seismic section (Inline 10590)

\subsection{Structural surface interpretation}

The structural surface (time) of the three reservoirs are displayed respectively in Figure 9, Figure 10 and Figure 11 respectively below.

\subsubsection{Petrophysical evaluation and analysis of reservoir 1}

Reservoir 1 falls within $-2303.57 \mathrm{~ms}$ and $-1509.20 \mathrm{~ms}$ on the seismic section. At the upper part of this surface, the area where the wells were concentrated. The faults F8 and F7A dips in opposite direction forming an antithetic fault located on the flank of the closure forming an enhanced anticline.

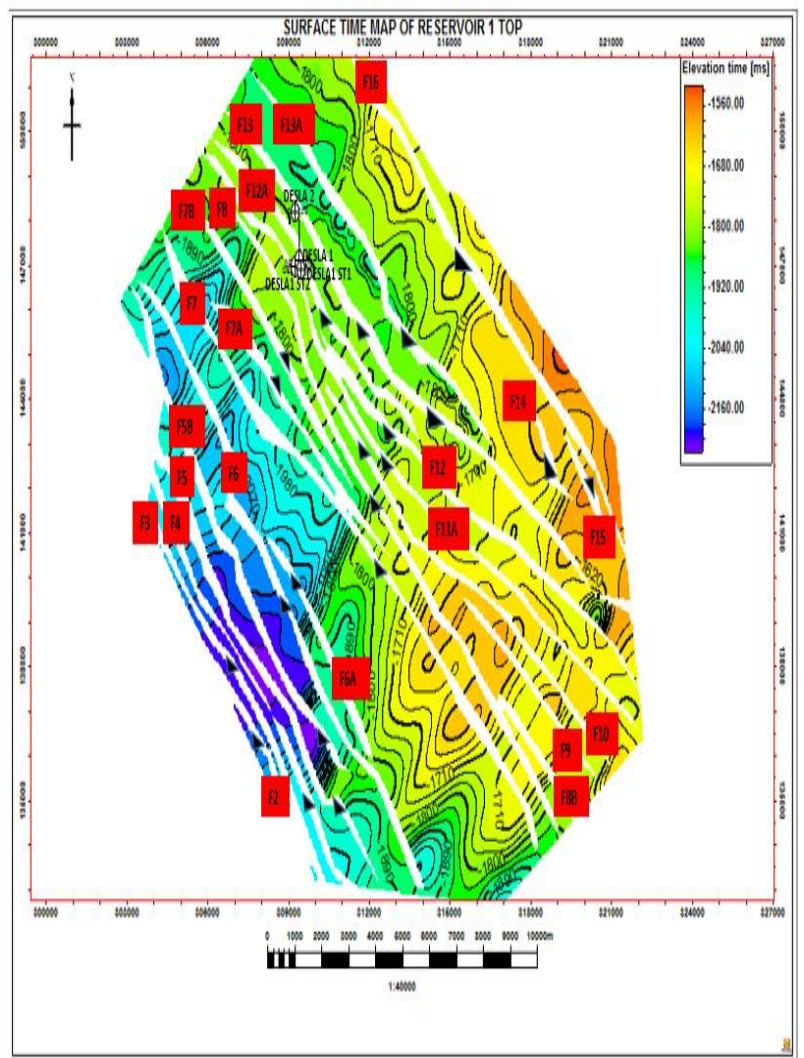

Figure 9. Surface time maps of Reservoir 1 showing the various faults that cut across it and their orientations
This is a typical hydrocarbon trap type common in the Niger Delta region. Also another major fault F16 and minor fault F15 forms an antithetic faults.

These faults might serve as a hydrocarbon trap and/or seal in terms of a fault assisted closure as seen on the far east end of the surface map in Figure 9.

Furthermore, fault F7 is also a regional fault that can deter further migration of hydrocarbon around the south-eastern closures. The latter two discussed locations are prospects for the better extraction of the hydrocarbon, therefore they should be further studied with the aid of quality reservoir models.

\subsubsection{Petrophysical evaluation and analysis of reservoir 2}

Reservoir 2 is the main prospect according to results generated from petrophysical evaluation and analysis. The structural surface (time) map of reservoir 2 is displayed in Figure 10. The surface (time) of reservoir 2 was picked within $-1725.50 \mathrm{~ms}$ and $3011.99 \mathrm{~ms}$.

The regional growth fault F16 form a fault assisted closure on the structural high at the far eastern end of this surface map. The major fault F7 can also serve as both trap and barrier for further migration of hydrocarbon as seen in the southern region of the map. This prospect might be the best location to drill developmental well for further exploitation of this promising reservoir. Furthermore, more data needs to acquired eastwards to further explore the emerging structural high.

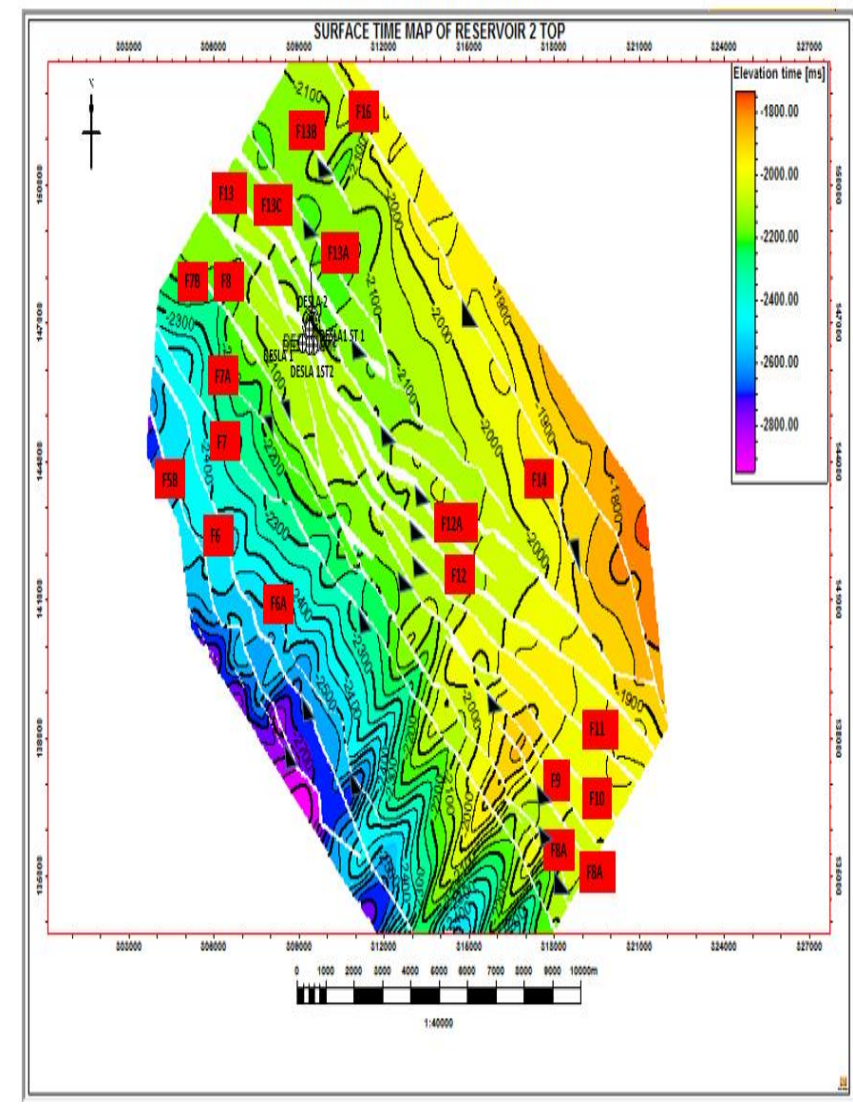

Figure 10. Surface time maps of Reservoir 2 showing the various faults that cut across it and their orientations

\subsubsection{Petrophysical evaluation and analysis of reservoir 3}

The last delineated and the deepest reservoir is Reservoir 3. The reservoir is very close to the previous reservoir unit. This surface (time) was picked within $-1709.25 \mathrm{~ms}$ and $3090.18 \mathrm{~ms}$. 
The regional growth fault F16 aslo cut across this reservoir and form fault assisted closure on the structural high at the far eastern end of the surface map.

The major fault F7 might also serve as barrier for further migration of hydrocarbon as seen in the southern region of the map. This prospect might be a good well location to further develop this reservoir. Furthermore, more data needs to acquired eastwards to further explore the emerging structural high. The structural surface (time) map of reservoir 3 can be seen in Figure 11 below.

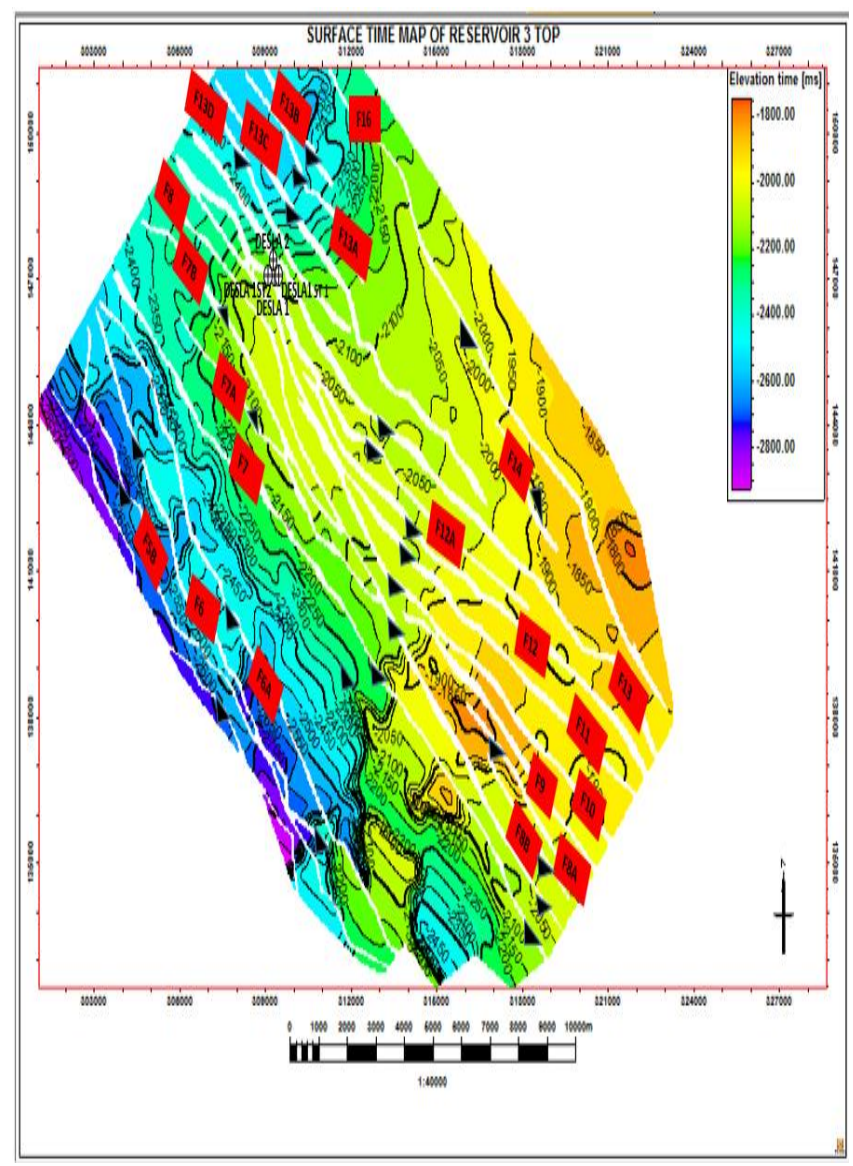

Figure 11. Surface time maps of Reservoir 3 showing the various faults that cut across it and their orientations

\section{CONCLUSION}

From the study, reservoir 2 is observed to be the most promising reservoir. It can be seen from the chart in Figure 6 that DESLA2 have the thickest delineated unit and also have the highest sand thickness. However, DESLA1ST2 is observed to have the highest net pay, a good net to gross, a reasonable effective porosity of about $20 \%$ with the highest hydrocarbon saturation of $82 \%$ which makes it the most promising available well for hydrocarbon extraction in this reservoir.

The prospect located at the southern part of both reservoir 2 and reservoir 3 as discussed above is a good well location that might help to enhance extraction of more economical quantity of hydrocarbon simultaneously from these close reservoirs. There is also need for an extended seismic data towards the eastern end of this study area to further evaluate and study the extent of the anticline of this area which might also be a prospective producing well location.
This study has being able to make judicious use of the limited data available to delineate and characterize reservoirs based on their hydrocarbon potential while identifying prospective well location that will enable effective extraction of the hydrocarbon in place. Furthermore, it is also recommended that more wells should be drilled at prospective location in order to provide more data that will contribute to the generation of quality reservoir models.

\section{ACKNOWLEDGMENT}

I will like to acknowledge my team for the successful completion of this study. I will like to thank Falade A.0. for his dedication and support throughout the project. I will also like to thank my supervisor Abe, J.S. of the Federal University of Technology Akure for his support and encouragement.

\section{REFERENCES}

[1] Peng XD, Wang XG, Tong LY, Li H, Li H, Lv XD, Chen YX. (2015). A new method for deliverability evaluation of offshore gas reservoirs with high temperature and pressure. Environmental and Earth Science Research Journal 2(1): 1-6. https://doi.org/10.18280/eesrj.02010

[2] Li M, Sang Q. (2014). The research on the method of identifying low resistivity reservoir in Zhusan depression of the Pearl River Mouth Basin. Environmental and Earth Science Research Journal 1(1): 11-16. https://doi.org/10.18280/eesrj.010103

[3] Adeoti L, Onyekachi N, Olatinsu O, Fatoba J, Bello M. (2014). Static reservoir modeling using well log and 3$\mathrm{D}$ seismic data in a KN field, offshore Niger Delta, Nigeria. International Journal of Geosciences 5: 93-106. https://doi.org/10.4236/ijg.2014.51011

[4] Abe SJ, Ayuk MA, Mogaji K, Kafisanwo OO. (2018). 3D spatial distribution of reservoir parameters for prospect identification in "Bizzy" field, Niger Delta. Research Journal of Environmental and Earth Sciences 10(1): 24-33. https://doi.org/10.19026/rjees.10.5864

[5] Kukkle H. (1995). Regional petroleum geology of the world, Part II, Africa, America, Australia and Antarctica. Gebruder Borntraeger 1: 143-172.

[6] Tuttle MLW, Charpentier RR, Brownfield ME. (1990). Tertiary Niger Delta (Akata-Agbada) Petroleum System. United State Geological Survey, 3-5.

[7] Whiteman AJ. (1982). Nigeria, its petroleum geology, resources and potential. Springers Netherland 1: 165394. https://doi.org/10.1007/978-94-009-7361-9

[8] Klett TR, Ahlbrandt TS, Schmoker JW, Dolton JL. (1997). Ranking of the world's oil and gas provinces by known petroleum volumes. United State Geological Survey Open-file Report, 97-463. https://doi.org/101.3133/ofr97463

[9] Kaplan A, Lusser CU, Norton IO. (1994). Tectonic map of the world, panel 10. American Association of Petroleum Geologists.

[10] Hosper J (1965). Gravity field and structure of Niger Delta, Nigeria, West Africa. Geology Society of American Bulletin 76(4): 407-422. http://doi.org/10.1130/0016- 
7606(1965)76[407:GFASOT]2.0.CO;2

[11] Avbovbo AA. (1978). Tertiary lithostratigraphy of Niger Delta. American Association of Petroleum Geologists Bulletin 62: 295-300. https://doi.org/10.1306/C1EA482E-16C9-1107$8645000102 \mathrm{C} 1865 \mathrm{D}$

[12] Weber KJ. (1987). Hydrocarbon distribution pattern in Nigerian growth fault structures controlled by structural style and stratigraphy. Journal of Petroleum Science and Engineering 1: 1-12. https://doi.org/10.1016/09204105(87)90001-5

[13] Doust H, Omatsola M. (1990). Petroleum geology of the Niger delta. Geological Society, London, Special

Publications

50:

$365-365$.

https://doi.org/10.1144/GSL.SP.1990.050.01.21

\section{NOMENCLATURE}

NT

GT

NTG

NP

Vsh

$\mathrm{Sw}$

Shc
Net Thickness, $\mathrm{ft}$

Gross Thickness, $\mathrm{ft}$

Net to Gross Thickness, \%

Net Pay Thickness, $\mathrm{ft}$

Volume of shale, $\%$

Water Saturation, \%

Hydrocarbon Saturation, \% 